\title{
Energy Productivity Convergence in Asian Countries: A Spatial Panel Data Approach
}

\author{
Dipa Adhikari ${ }^{1} \&$ Yanying Chen $^{1}$ \\ ${ }^{1}$ School of Economics, Dalian University of Technology, Dalian, P. R. China \\ Correspondence: Dipa Adhikari, School of Economics, Dalian University of Technology, Dalian, 116024, P. R. \\ China. E-mail: dipadhikari@hotmail.com
}

Received: April 7, 2014

Accepted: April 21, 2014

Online Published: June 25, 2014

doi:10.5539/ijef.v6n7p94

URL: http://dx.doi.org/10.5539/ijef.v6n7p94

\begin{abstract}
The main purpose of this paper is to examine the convergence of energy productivity for 35 Asian countries over the period 1993-2010. These 35 countries are divided into five different geographical regions, namely, South East Asia, South Asia, North East Asia, North Asia and West Asia. We first use the sigma-convergence approach to investigate the disparity of energy productivity over time and find weak evidence of sigma-convergence process in energy productivity for all sample countries and mixed evidence for sub-sample countries. We then estimate the beta-convergence model by using the spatial panel data approach and find an existence of beta-convergence process in energy productivity for the whole set of sample countries and North East Asia. Moreover, we find mixed evidence of beta-convergence process in energy productivity for South East Asia, North Asia and West Asia. In South Asia, we find strong evidence of divergence process in energy productivity over the study period.
\end{abstract}

Keywords: energy productivity, convergence, spatial panel data models, Asia

\section{Introduction}

Energy use plays an important role in the process of economic development in every corner of the world. In recent years, energy use is increasing at fastest rate, particularly in Asian nations due to the high population growth, fast urbanization, industrialization, improving the life quality of people and rapid economic development. Asia account 39\% of the world GDP in 2010 (International Monetary Finance (IMF), 2011) and its economic development patterns have been highly affected global economy. This economic growth achieved in Asia as a result of the high energy use. The International Energy Agency projections in 2010 showed that Asia's primary energy demand is estimated to grow by $2.3 \%$ per year between 2008 and 2035 (IEA, 2010, p. 85).

As known, there is a wide spatial variation of energy use within the Asia region. The energy use in this region is not only affected by the economic behavior of the individual country but also greatly affected the economic condition of the adjacent countries. Therefore, it is needed to investigate whether there exists the convergence of energy productivity that provide useful information for making effective policy to improve the energy productivity in a large extent within the Asian countries.

A large number of researchers have investigated convergence of per capita income (Note 1) and labor productivity and total factor productivity (Note 2) across countries and regions. Most of the prior studies have been carried out in the context of economic growth. Over the last few years, energy-economics has become a highly popular topic in the area of environment and economic development. A number of theoretical and empirical studies have been basically focused on convergence of energy-related issues for different countries or regions covering various time periods (for example, Strazicich \& List, 2003; Aldy, 2006; Ezcurra, 2007a; Romero-Avila, 2008; Westerlund \& Basher, 2008; Liddle, 2009; Jakob et al., 2012; Meng et al., 2013; among others). These studies mainly focused on convergence of carbon-dioxide emissions, electricity and energy use. While some recent studies have investigated the energy intensity or energy productivity convergence in energy-economics literature using different techniques (see for example, Sun, 2002; Miketa \& Mulder, 2005; Markandya et al., 2006; Ezcurra, 2007b; Mulder \& De Groot, 2007; Le Pen \& Sevi, 2010; Liddle, 2010; Duro \& Padilla, 2011) for developed and developing countries. Broadly speaking, these analyses of energy intensity or productivity convergence at various scales and using different techniques have yielded mixed or conflicting results. 
As aforementioned, most of these studies highly ignored the spatial effects of energy productivity convergence. More recently, three studies (Mulder et al., 2011; Yu, 2012; Wan et al., 2013) have primarily focused on convergence of energy intensity or productivity using the spatial panel data technique. Mulder et al. (2011) investigated the global energy productivity trends covering the period 1971-2001. They found cross-country variation of energy productivity development is influenced by the spatial effect of the energy productivity growth rates. Yu (2012) investigated the influential factors of China's regional energy intensity using the spatial panel data models for the period 1988-2007 and found the notable spillover effect between eastern and western China as well as the existence of the absolute beta-convergence of provincial energy intensity. Likewise, Wan et al. (2013) analyzed the trade-facilitated spillovers in convergence of energy productivity across 16 European Union countries during the period 1995-2005 by using the spatial panel data approach. The authors found an evidence of convergence in energy productivity for 16 European Union countries. Indeed, such types of studies have not been conducted for 35 Asian countries using spatial panel data models. Therefore, this study investigates the convergence of energy productivity for 35 Asian countries over the period 1993-2010.

The contributions of this work are three fold. First, we use the sigma-convergence approach to investigate the disparity of energy productivity over time. Second, we employ the beta-convergence approach to estimate whether there exists an evidence of convergence in energy productivity by using spatial panel data models based on the following works (Barro \& Sala-i-Martin, 1992, 1995). Two kinds of spatial panel data models are used here to deal with spatial dependence of observations such as the spatial lag (SAR) panel data model and the spatial error (SEM) panel data model. To our best knowledge, this is the first systematic in-depth study on convergence of energy productivity by using the spatial panel data models in Asian countries. Third, considering geographical variations in Asia, we divided 35 Asian countries into five different geographical regions, namely, South East Asia, South Asia, North East Asia, North Asia and West Asia. Most of the previous studies have not been carried out both on the whole set of countries as well as five different geographical regions.

The remainder part of the present study is organized as follows. Section 2 briefly describes the data sources and variables. Section 3 presents the methodology used in this study. Section 4 provides the results and discussion of the study. Finally, section 5 gives the conclusions and some policy implications.

\section{Data Sources and Variables Description}

In our study we use the panel data of 35 Asian countries over the period 1993-2010. We divide these 35 Asian countries into five geographical regions: South East Asia (Brunei, Indonesia, Malaysia, Philippines, Singapore, Thailand and Vietnam), South Asia (Bangladesh, India, Nepal, Pakistan and Sri Lanka), North East Asia (China, Hong Kong, Japan, Mongolia and South Korea), North Asia (Kazakhstan, Kyrgyz Republic, Tajikistan, Turkmenistan and Uzbekistan), West Asia (Bahrain, Iran, Iraq, Israel, Jordan, Lebanon, Oman, Qatar, Saudi Arabia, Syrian Arab Republic, United Arab Emirates, Turkey and Yemen). The annual data on energy use (E) (kg of oil equivalent per capita) is taken from the World Bank, World Development Indicators (WDI, 2013) online data base. The annual data on real gross domestic product (GDP) per capita (constant 2005 US dollars), consumer price (US dollars), investment share (constant 2005 US dollars) and trade openness (constant 2005 price \%) are taken from the Penn World Table, Version 7.1 (Heston et al., 2012) online data base. Geographic information of all selected Asian countries is obtained from maps of World (Note 3).

In this empirical analysis, energy productivity (EP) is simply defined as the output divided by energy use (which is the inverse of energy intensity). The data on consumer price variable (measured in US dollars) is used as a proxy for energy price (P). We use the investment share variable, i.e., simply the ratio of natural $\log$ of investment share and GDP, as a proxy for the investment (I). Similarly, we use the trade openness variable, i.e., the natural log ratio of trade openness and GDP, as a proxy for the trade openness (TO). All variables are transformed into natural logarithms and the countries and length of the period were dictated by the data availability of variables.

Figure 1 exhibits the log of energy productivity for all sample countries as well as sub-sample countries, namely, South East Asia, South Asia, North East Asia, North Asia and West Asia during the period 1993-2010. The figure clearly shows that energy productivity trend is growing over time in Asian countries, which implies that the Asian economy tends to catching up the technological leader countries. 


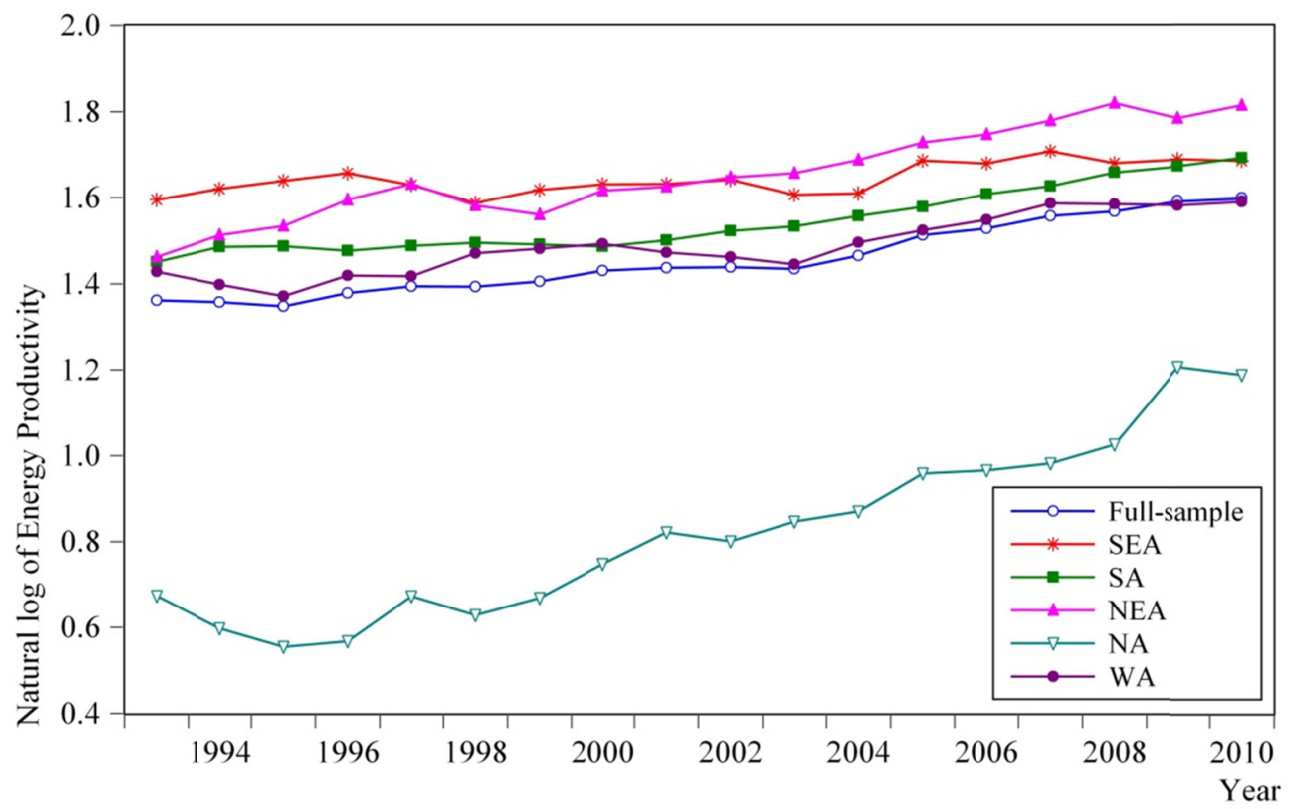

Figure 1. Energy productivity for the full-sample countries and five different sub-sample countries (SEA-South East Asia, SA-South Asia, NEA-North East Asia, NA-North Asia, WA-West Asia) over the period 1993-2010

Table 1 reports the average annual growth rates of the variables for all sample countries and five sub-sample countries over the period 1993-2010.

Table 1. Average annual growth rates for the period 1993-2010

\begin{tabular}{lcccccc}
\hline Variables & All sample countries & South East Asia & South Asia & North East Asia & North Asia & West Asia \\
\hline $\ln (\mathrm{EP})$ & 1.4558 & 1.6443 & 1.5454 & 1.6549 & 0.8209 & 1.4876 \\
$\ln (\mathrm{E})$ & 7.3126 & 7.2996 & 5.8284 & 7.6262 & 7.1943 & 7.8153 \\
$\ln (\mathrm{GDP})$ & 8.7684 & 8.9439 & 7.3738 & 9.2810 & 8.0159 & 9.3029 \\
$\ln (\mathrm{P})$ & 3.8961 & 3.9339 & 3.5420 & 4.2359 & 3.2919 & 4.1137 \\
$\ln (\mathrm{I})$ & 0.3675 & 0.3674 & 0.4161 & 0.3897 & 0.3403 & 0.3507 \\
$\ln (\mathrm{TO})$ & 0.5083 & 0.5455 & 0.5027 & 0.4684 & 0.5793 & 0.4783 \\
\hline
\end{tabular}

Note. All variables are in natural logarithms.

\section{Methodology}

\subsection{Convergence Model Specification}

Over the last twenty five years in classical literature there are two widely used convergence concepts, namely, sigma-convergence and beta-convergence (Barro, 1991; Barro \& Sala-i-Martin, 1992). The sigma-convergence approach refers to the various measures of standard deviation or coefficient of variation of productivity over the specific time period (Fan \& Casetti, 1994; Bernard \& Jones, 1996b; Carlino \& Mills, 1996; Cuadrado-Roura et al., 1999). The difference in energy productivity is calculated by using the standard deviation that can be defined as follows:

$$
\sigma_{i t}=\sqrt{\frac{1}{n} \sum_{i=1}^{n}\left(\ln E P_{i t}-\ln \overline{E P_{i t}}\right)^{2}}
$$

where $i$ and $t$ denote the countries and time period, respectively, $E P_{i t}$ is the energy productivity, $\overline{E P_{i t}}$ is the mean value of the energy productivity over time.

The beta-convergence approach used in this study to examine the convergence or divergence of energy productivity is based on the neo-classical growth theory (Solow, 1956; Swan, 1956) (Note 4). The beta-convergence suggests that the regions or countries have low initial levels of productivity tend to grow 
comparatively faster than those with high initial levels and catching up to rich regions or countries (Barro, 1991; Barro \& Sala-i-Martin, 1992). Over the last two and half decades, the beta-convergence approach has become one of the most convincing concepts in the macroeconomic growth literature. The beta-convergence concept usually considers either unconditional (absolute) convergence or conditional (relative) convergence. Here we present the absolute beta-convergence model (Barro \& Sala-i-Martin, 1992, 1995) that is given in equation (2) as follows:

$$
\ln \left(E P_{i, t+1} / E P_{i t}\right)=a+\beta \ln E P_{i t}+\varepsilon_{i t}
$$

where $i$ and $t$ denote the countries and time period, respectively, $a$ is the intercept, $\ln \left(E P_{i, t+1} / E P_{i t}\right)$ is the annual average growth rate of energy productivity, $\ln E P_{i t}$ is the initial level of energy productivity and $\varepsilon_{i t}$ is the error term. A statistically significant and negative sign of the estimated $\beta$-coefficient implies the existence of beta-convergence hypothesis (Baumol, 1986).

We further need to identify whether the existence of conditional convergence in energy productivity for Asian countries by adding the control variables in equation (2) to control for factors determining with steady state. Thus, the conditional beta-convergence model can be written here as follows:

$$
\ln \left(E P_{i, t+1} / E P_{i t}\right)=a+\beta \ln E P_{i t}+x_{i t}+\varepsilon_{i t}
$$

where $x_{i t}$ is the control variables and other remaining terms are the identical as described in equation (2). In this study, we use three control variables: energy price, investment and trade openness (Note 5). We assume that: (1) energy price has a positive effect on energy productivity growth, which gives an incentive for improvement of energy efficiency in Asia, (2) higher investment will increase energy productivity growth, and (3) trade openness has a positive impact on energy productivity growth that would contribute to enhance energy productivity growth through the technology transfer in Asia.

\subsection{Convergence Model with Spatial Econometric Perspective}

Now we move to the spatial econometric models that apply the convergence models in equations (2) and (3) for the analysis of energy productivity convergence in Asian countries over the period 1993-2010. The spatial econometric models can be applied in various ways, here we used the most widely models, namely, the spatial lag panel data model and the spatial error panel data model (Note 6). The description of the spatial lag panel data and spatial error panel data models can be found in detail (Elhorst, 2003; Anselin et al., 2008) and herein we briefly introduce these two models used in this analysis. First, we specify the spatial lag panel data model in equations (4) and (5), respectively, as follows:

$$
\begin{array}{r}
\ln \left(E P_{i, t+1} / E P_{i t}\right)=\alpha+\sum_{j=1}^{N} \rho w_{i j} \ln \left(E P_{i, t+1} / E P_{i t}\right)+\beta \ln E P_{i t}+\mu_{i}+\eta_{t}+\varepsilon_{i t} \\
\ln \left(E P_{i, t+1} / E P_{i t}\right)=\alpha+\sum_{j=1}^{N} \rho w_{i j} \ln \left(E P_{i, t+1} / E P_{i t}\right)+\sum_{j=1} x_{i t} k \beta_{k}+\beta \ln E P_{i t}+\mu_{i}+\eta_{t}+\varepsilon_{i t}
\end{array}
$$

where $\rho$ is a spatial autoregressive coefficient, $u_{i}$ and $\eta_{t}$ represent the individual effect and the time effect (that are controlled by the traditional panel data method), respectively, and $w_{i j}$ is the spatial weight matrix elements of countries $i$ and $j$ (Note 7).

Second, we specify the spatial error panel data model in equations (6) and (7), respectively, as follows:

$$
\begin{gathered}
\ln \left(E P_{i, t+1} / E P_{i t}\right)=\alpha+\beta \ln E P_{i t}+\mu_{i}+\eta_{t}+\mathrm{u}_{i t} \\
\mathrm{u}_{i t}=\sum_{j=1}^{N} \lambda \mathrm{W}_{i j} \varepsilon_{i t}+\varepsilon_{i t} \\
\ln \left(E P_{i, t+1} / E P_{i t}\right)=\alpha+\sum_{j=1} x_{i t}^{k} \beta_{k}+\beta \ln E P_{i t}+\mu_{i}+\eta_{t}+\mathrm{u}_{i t} \\
\mathrm{u}_{i t}=\sum_{j=1}^{N} \lambda \mathrm{W}_{i j} \varepsilon_{i t}+\varepsilon_{i t}
\end{gathered}
$$

where $\lambda$ is a spatial error coefficient and other remaining notations are defined already in equations (4) and (5). 


\section{Results and Discussion}

\subsection{Sigma-Convergence}

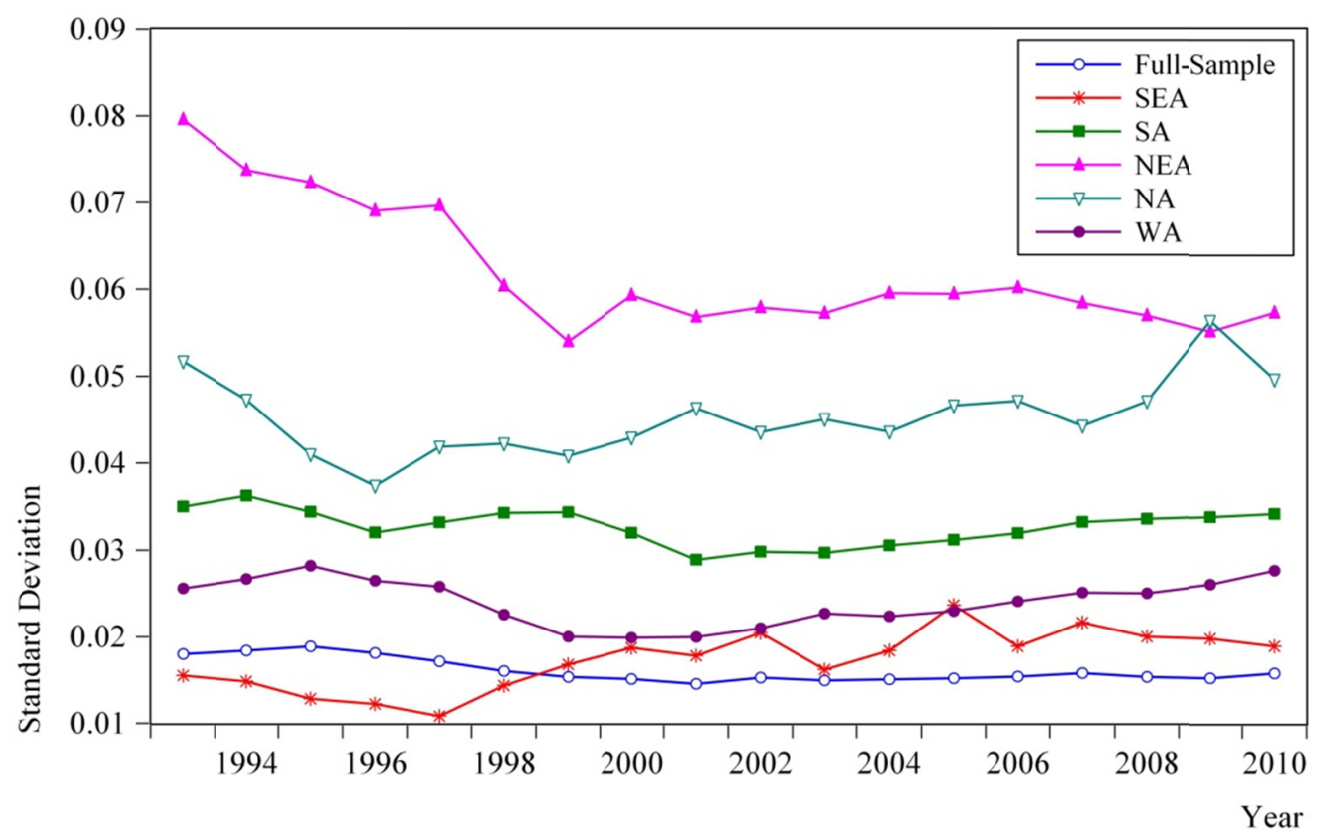

Figure 2. Sigma- (i.e., standard deviation) convergence in energy productivity for the full-sample countries and five different sub-sample countries (SEA-South East Asia, SA-South Asia, NEA-North East Asia, NA-North Asia, WA-West Asia) over the period 1993-2010

Figure 2 displays the sigma-convergence of energy productivity for all sample countries as well as South East Asia, South Asia, North East Asia, North Asia and West Asia from 1993 to 2010. It can be noted from Figure 2 that the sigma-convergence of energy productivity for all sample countries does not exhibit a downward trend over the period 1993-2010. This implies that there is a weak evidence of sigma-convergence process in Asia. However, sub-sample countries demonstrate the mixed trend of sigma-convergence between 1993 and 2010 (Figure 2). South East Asian countries indicate a quite convergence before 1997 and divergence post 1997. There is no clear evidence of either convergence or divergence in South Asian countries over the entire study period. North East Asian countries exhibit a clear evidence of convergence for the period 1993-2010. North Asian countries show a quite convergence from 1993 to 1996 and divergence after 1996. West Asian countries demonstrate the slight convergence between 1993 and 2001 and divergence since 2001, which is more or less similar to South Asian countries.

Overall, the sigma-convergence of energy productivity for all sample countries and sub-sample countries is somehow convergence and divergence. Thus, it is concluded that there is a mixed evidence of sigma-convergence over the entire study period.

\subsection{Beta-Convergence}

In the present study, we use the spatial panel data models with fixed effects estimator (Note 8). Tables 2a, 2b, 3a and $3 \mathrm{~b}$ summarize the estimated results of an absolute beta-convergence and conditional beta-convergence using the SAR panel data and SEM panel data models for the whole set of Asian countries and separately for South East Asia, South Asia, North East Asia, North Asia and West Asia over the period 1993-2010. Columns 1 to 3 report estimation results (SAR panel data model) of spatial fixed effects, time period effects, and both spatial and time period effects, respectively. Likewise, Columns 4 to 6 present estimation results (SEM panel data model) of spatial fixed effects, time period effects, and both spatial and time period effects, respectively. It is important to note that we select here three year time intervals (1993-1995, 1996-1998, 1999-2001, 2002-2004, 2005-2007 and 2008-2010) to minimize the effects of fluctuations in business cycle and serial correlation on the error term as (Mulder et al., 2011).

The estimated results of an absolute beta-convergence using the SAR panel data and SEM panel data models for 
all selected sample countries as well as for sub-groups are reported in Tables $2 \mathrm{a}-\mathrm{b}$. The estimated results of the $\beta$-coefficient are negative and statistically significant at the $1 \%$ level for the sample of 35 Asian countries (Columns (1)-(6) in Table 2a). This means that there exists an absolute beta-convergence process of energy productivity for these Asian countries over the study period. The estimated results of spatial autoregressive coefficient $(\rho)$ and spatial error coefficient $(\lambda)$ are negative signs and statistically insignificant for all sample countries (Table 2a). Moreover, we find similar results for North East Asia and West Asia (Table 2b). We find mixed evidence of energy productivity convergence in the South East Asia and North Asia regions over the study period (Table $2 \mathrm{~b}$ ). In contrast, we find no evidence of energy productivity convergence in the South Asia region for the study period (Table 2b). The estimated results of spatial autoregressive coefficient $(\rho)$ and spatial error coefficient $(\lambda)$ are negative signs, but statistically significant (Columns (2), (3), (5), (6) in Table 2b).

Overall, we find evidence of an absolute beta-convergence which suggests that countries having comparatively low initial energy productivity levels catching up to high income countries. Thus, we conclude that an absolute beta-convergence process in favor of energy productivity growth in the whole set of sample countries as well as two sub-samples: North East Asia and West Asia.

Table 2a. Estimation results of the absolute beta-convergence for all 35 sample countries

\begin{tabular}{|c|c|c|c|c|c|c|}
\hline & \multicolumn{3}{|c|}{ Spatial lag (SAR) panel data model } & \multicolumn{3}{|c|}{ Spatial error (SEM) panel data model } \\
\hline & $\begin{array}{l}\text { Spatial fixed } \\
\text { effects (1) }\end{array}$ & $\begin{array}{l}\text { Time-Period } \\
\text { fixed effects (2) }\end{array}$ & $\begin{array}{l}\text { Spatial and time-period } \\
\text { fixed effects ( } 3 \text { ) }\end{array}$ & $\begin{array}{l}\text { Spatial fixed } \\
\text { effects (4) }\end{array}$ & $\begin{array}{l}\text { Time-period } \\
\text { fixed effects (5) }\end{array}$ & $\begin{array}{l}\text { Spatial and time-period } \\
\text { fixed effects (6) }\end{array}$ \\
\hline $\ln (\mathrm{EP})$ & $\begin{array}{l}-0.0807 * * * \\
(-4.3164)\end{array}$ & $\begin{array}{l}-0.0761 * * * \\
(-3.958)\end{array}$ & $\begin{array}{l}-0.0847 * * * \\
(-4.338)\end{array}$ & $\begin{array}{l}-0.0808 * * * \\
(-4.3189)\end{array}$ & $\begin{array}{l}-0.0762 * * * \\
(-3.9623)\end{array}$ & $\begin{array}{l}-0.0848 * * * \\
(-4.3392)\end{array}$ \\
\hline$\rho$ & $\begin{array}{l}-0.0370 \\
(-0.3375)\end{array}$ & $\begin{array}{l}-0.0340 \\
(-0.3078)\end{array}$ & $\begin{array}{l}-0.0390 \\
(-0.3528)\end{array}$ & & & \\
\hline$\lambda$ & & & & $\begin{array}{l}-0.0100 \\
(-0.0895)\end{array}$ & $\begin{array}{l}-0.0109 \\
(-0.0627)\end{array}$ & $\begin{array}{l}-0.0250 \\
(-0.2228)\end{array}$ \\
\hline $\mathrm{R}^{2}$ & 0.2363 & 0.0751 & 0.2421 & 0.2358 & 0.0746 & 0.2415 \\
\hline
\end{tabular}

Note. The t-values are in parentheses. *, ** and *** indicate statistical significance at the $10 \%, 5 \%$ and $1 \%$ levels of significance.

Table 2b. Estimation results of the absolute beta-convergence for five geographical regions

\begin{tabular}{|c|c|c|c|c|c|c|}
\hline & \multicolumn{3}{|c|}{ Spatial lag (SAR) panel data model } & \multicolumn{3}{|c|}{ Spatial error (SEM) panel data model } \\
\hline & $\begin{array}{l}\text { Spatial fixed } \\
\text { effects (1) }\end{array}$ & $\begin{array}{l}\text { Time-period } \\
\text { fixed effects (2) }\end{array}$ & $\begin{array}{l}\text { Spatial and time-period } \\
\text { fixed effects (3) }\end{array}$ & $\begin{array}{l}\text { Spatial fixed } \\
\text { effects (4) }\end{array}$ & $\begin{array}{l}\text { Time-period } \\
\text { fixed effects (5) }\end{array}$ & $\begin{array}{l}\text { Spatial and time-period } \\
\text { fixed effects }(6)\end{array}$ \\
\hline \multicolumn{7}{|c|}{ South East Asia } \\
\hline $\ln (\mathrm{EP})$ & $\begin{array}{l}-0.0774 \\
(-1.0293)\end{array}$ & $\begin{array}{l}-0.1782 * * * \\
(-2.4049)\end{array}$ & $\begin{array}{l}-0.1670 * * \\
(-2.3062)\end{array}$ & $\begin{array}{l}-0.0553 \\
(-0.8088)\end{array}$ & $\begin{array}{l}-0.1011^{*} \\
(-1.4241)\end{array}$ & $\begin{array}{l}-0.0901 * \\
(-1.3336)\end{array}$ \\
\hline$\rho$ & $\begin{array}{l}-0.2120 \\
(-1.0170)\end{array}$ & $\begin{array}{l}-0.8450 * * * \\
(-4.9306)\end{array}$ & $\begin{array}{l}-0.9060 * * * \\
(-5.5500)\end{array}$ & & & \\
\hline$\lambda$ & & & & $\begin{array}{l}-0.1810 \\
(-0.8673)\end{array}$ & $\begin{array}{l}-0.8049 * * * \\
(-4.4388)\end{array}$ & $\begin{array}{l}-0.8660 * * * \\
(-5.0100)\end{array}$ \\
\hline $\mathrm{R}^{2}$ & 0.1460 & 0.6024 & 0.6415 & 0.1036 & 0.2219 & 0.2857 \\
\hline \multicolumn{7}{|c|}{ South Asia } \\
\hline $\ln (\mathrm{EP})$ & $\begin{array}{l}-0.0085 \\
(-0.3137)\end{array}$ & $\begin{array}{l}-0.0029 \\
(-0.0816)\end{array}$ & $\begin{array}{l}0.0089 \\
(0.2388)\end{array}$ & $\begin{array}{l}-0.0068 \\
(-0.2751)\end{array}$ & $\begin{array}{l}0.0160 \\
(0.3784)\end{array}$ & $\begin{array}{l}0.0314 \\
(0.7069)\end{array}$ \\
\hline$\rho$ & $\begin{array}{l}-0.0085 \\
(-0.3137)\end{array}$ & $\begin{array}{l}-0.7930 * * * \\
(-4.0575)\end{array}$ & $\begin{array}{l}-0.7670 * * * \\
(-3.8326)\end{array}$ & & & \\
\hline$\lambda$ & & & & $\begin{array}{l}-0.1460 \\
(-0.6052)\end{array}$ & $\begin{array}{l}-0.8020 * * * \\
(-4.1395)\end{array}$ & $\begin{array}{l}-0.8049 * * * \\
(-4.1669)\end{array}$ \\
\hline $\mathrm{R}^{2}$ & 0.0750 & 0.4570 & 0.4721 & 0.0567 & 0.1427 & 0.1873 \\
\hline North & ast Asia & & & & & \\
\hline $\ln (\mathrm{EP})$ & $\begin{array}{l}-0.0841 * * * \\
(-3.0303)\end{array}$ & $\begin{array}{l}-0.1177 * * * \\
(-2.8590)\end{array}$ & $\begin{array}{l}-0.1066^{* * *} \\
(-2.5446)\end{array}$ & $\begin{array}{l}-0.0553 * * * \\
(-2.9363)\end{array}$ & $\begin{array}{l}-0.1549 * * * \\
(-3.4696)\end{array}$ & $\begin{array}{l}-0.1471 * * * \\
(-3.1687)\end{array}$ \\
\hline$\rho$ & $\begin{array}{l}-0.6420 * * * \\
(-3.0677) \\
\end{array}$ & $\begin{array}{l}-0.9810 * * * \\
(-6.7098) \\
\end{array}$ & $\begin{array}{l}-0.9760 * * * \\
(-6.5737) \\
\end{array}$ & & & \\
\hline
\end{tabular}




\begin{tabular}{|c|c|c|c|c|c|c|}
\hline \multicolumn{4}{|l|}{$\lambda$} & \multirow{3}{*}{$\begin{array}{l}-0.6080^{* * *} \\
(-2.7123) \\
0.2255 \\
\end{array}$} & \multirow{3}{*}{$\begin{array}{l}-0.9740 \text { *** } \\
(-6.2298) \\
0.1743 \\
\end{array}$} & \multirow{3}{*}{$\begin{array}{l}-0.9780 * * * \\
(-6.2948) \\
0.2725\end{array}$} \\
\hline & & & & & & \\
\hline $\mathrm{R}^{2}$ & 0.4491 & 0.6395 & 0.6731 & & & \\
\hline \multicolumn{7}{|c|}{ North Asia } \\
\hline \multirow[t]{2}{*}{$\ln (\mathrm{EP})$} & $-0.0870 *$ & 0.0261 & 0.0269 & $-0.0825 * *$ & 0.02169 & 0.0224 \\
\hline & $(-1.7444)$ & $(0.3135)$ & $(0.3209)$ & $(-2.1920)$ & $(0.2424)$ & $(0.2496)$ \\
\hline \multirow[t]{2}{*}{$\rho$} & -0.2470 & $-0.5880 * * *$ & $-0.5589 * *$ & & & \\
\hline & $(-1.0122)$ & $(-2.3604)$ & $(-2.2327)$ & & & \\
\hline \multirow[t]{2}{*}{$\lambda$} & & & & $-0.3399 *$ & $-0.5580 * *$ & $-0.4860 * *$ \\
\hline & & & & $(-1.3475)$ & $(-2.2233)$ & $(-2.0693)$ \\
\hline $\mathrm{R}^{2}$ & 0.1435 & 0.3188 & 0.3386 & 0.0949 & 0.1355 & 0.1750 \\
\hline \multicolumn{7}{|c|}{ West Asia } \\
\hline \multirow[t]{2}{*}{$\ln (\mathrm{EP})$} & $-0.1272 * * *$ & $-0.1802 * * *$ & $-0.3058 * * *$ & $-0.1520 * * *$ & $-0.1880 * * *$ & $-0.3120 * * *$ \\
\hline & $(-2.6683)$ & $(-3.2115)$ & $(-4.9863)$ & $(-3.0846)$ & $(-3.2371)$ & $(-4.9953)$ \\
\hline \multirow[t]{2}{*}{$\rho$} & -0.1970 & $-0.2819^{*}$ & $-0.2450 *$ & & & \\
\hline & $(-1.1195)$ & $(-1.5500)$ & $(-1.4144)$ & & & \\
\hline \multirow[t]{2}{*}{$\lambda$} & & & & 0.0849 & $-0.2740 *$ & -0.2130 \\
\hline & & & & $(0.5083)$ & $(-1.4810)$ & $(-1.1612)$ \\
\hline $\mathrm{R}^{2}$ & 0.3174 & 0.1807 & 0.4640 & 0.3016 & 0.1447 & 0.4455 \\
\hline
\end{tabular}

Note. The t-values are in parentheses. *,** and $* * *$ indicate statistical significance at the $10 \%, 5 \%$ and $1 \%$ levels of significance.

Now we move to the conditional beta-convergence model. In this study, we expect energy price, investment and trade openness are positively related with energy productivity growth. Tables $3 \mathrm{a}-\mathrm{b}$ show the estimated results of conditional beta-convergence using the SAR panel data and SEM panel data models for the full sample countries and for sub-groups, namely, South East Asia, South Asia, North East Asia, North Asia and West Asia.

We start the estimated results for the full sample countries that are reported in Table 3a. The estimated results show that the $\beta$-coefficient is still negative and statistically significant in both SAR and SEM panel data models (Columns (1)-(6)) and other coefficients of the control variables have the anticipated signs except investment variable. The estimated coefficient on the trade openness variable is positively related with energy productivity growth and statistically significant (Columns (1)-(6) in Table 3a). This means that trade openness has a positive impact on energy productivity growth over the study period. Similarly, the estimated coefficient on the energy price variable is positively related with energy productivity growth and statistically significant as given in Columns (1) to (6) in Table 3a. In contrast, the estimated coefficient on the investment variable is negatively related with energy productivity growth, but statistically significant at the $1 \%$ level (Columns (1)-(6) in Table $3 a)$. The results of spatial autoregressive coefficient $(\rho)$ and spatial error coefficient $(\lambda)$ have negative signs and statistically insignificant (Columns (1), (2), (3) and (6) in Table 3a). The estimated results of spatial error coefficient $(\lambda)$ has positive sign, but insignificant effect on the adjoining economies (Columns (4) and (5) in Table 3a).

Moreover, we obtained quite dissimilar results when considering five different sub-groups, namely, South East Asia, South Asia, North East Asia, North Asia and West Asia. We consider 7 countries from the South East Asia region and the estimated $\beta$-coefficient in these 7 countries is negative and statistically significant in both SAR and SEM panel data models (Columns (1)-(6) in Table 3b). It seems that there exists a conditional beta-convergence process in energy productivity growth for the South East Asia region. We find energy price and trade openness variables have the anticipated signs (Table 3b). The estimated coefficient on the trade openness variable is statistically significant and positive as indicated in Columns (1) to (6). It means that trade openness has a positive impact on energy productivity growth over the study period. The estimated coefficient on the energy price variable is positively related with energy productivity growth and statistically significant (only Columns (1) and (4)). On the other hand, the estimated coefficient on the investment variable is negatively related with the energy productivity growth and statistically significant as demonstrated in Columns (1), (3) and (4). The spatial autoregressive coefficient $(\rho)$ and spatial error coefficient $(\lambda)$ have negative signs, but statistically significant as reported in Columns (2), (3), (5) and (6) in Table $3 \mathrm{~b}$. 
Table 3a. Estimation results of the conditional beta-convergence for all 35 sample countries

\begin{tabular}{|c|c|c|c|c|c|c|}
\hline & \multicolumn{3}{|c|}{ Spatial lag (SAR) panel data model } & \multicolumn{3}{|c|}{ Spatial error (SEM) panel data model } \\
\hline & $\begin{array}{l}\text { Spatial fixed } \\
\text { effects (1) }\end{array}$ & $\begin{array}{l}\text { Time-period } \\
\text { fixed effects (2) }\end{array}$ & $\begin{array}{l}\text { Spatial and time-period } \\
\text { fixed effects (3) }\end{array}$ & $\begin{array}{l}\text { Spatial fixed } \\
\text { effects (4) }\end{array}$ & $\begin{array}{l}\text { Time-period } \\
\text { fixed effects (5) }\end{array}$ & $\begin{array}{l}\text { Spatial and time-period } \\
\text { fixed effects (6) }\end{array}$ \\
\hline $\ln (\mathrm{EP})$ & $\begin{array}{l}-0.0923 * * * \\
(-4.6082)\end{array}$ & $\begin{array}{l}-0.0839 * * * \\
(-4.1629)\end{array}$ & $\begin{array}{l}-0.0932 * * * \\
(-4.4988)\end{array}$ & $\begin{array}{l}-0.0928 * * * \\
(-4.6257)\end{array}$ & $\begin{array}{l}-0.0841 * * * \\
(-4.1687)\end{array}$ & $\begin{array}{l}-0.0933^{* * *} \\
(-4.5045)\end{array}$ \\
\hline $\ln (\mathrm{P})$ & $\begin{array}{l}0.0303 * \\
(1.4159)\end{array}$ & $\begin{array}{l}0.0302 * \\
(1.3936)\end{array}$ & $\begin{array}{l}0.0313^{*} \\
(1.4610)\end{array}$ & $\begin{array}{l}0.0304 * \\
(1.4162)\end{array}$ & $\begin{array}{l}0.0302 * \\
(1.3939)\end{array}$ & $\begin{array}{l}0.0314^{*} \\
(1.4653)\end{array}$ \\
\hline $\ln (\mathrm{I})$ & $\begin{array}{l}-0.6123 * * * \\
(-4.0235)\end{array}$ & $\begin{array}{l}-0.7136^{* * *} \\
(-4.7527)\end{array}$ & $\begin{array}{l}-0.6543 * * * \\
(-4.2342)\end{array}$ & $\begin{array}{l}-0.6175 * * * \\
(-4.0578)\end{array}$ & $\begin{array}{l}-0.7142 * * * \\
(-4.7568)\end{array}$ & $\begin{array}{l}-0.6547 * * * \\
(-4.2362)\end{array}$ \\
\hline $\ln (\mathrm{TO})$ & $\begin{array}{l}0.2399 * \\
(1.7656)\end{array}$ & $\begin{array}{l}0.4044 * * * \\
(2.8047)\end{array}$ & $\begin{array}{l}0.2927 * * \\
(2.0310)\end{array}$ & $\begin{array}{l}0.2403^{*} \\
(1.7641)\end{array}$ & $\begin{array}{l}0.4048 * * * \\
(2.8106)\end{array}$ & $\begin{array}{l}0.2944 * * \\
(2.0440)\end{array}$ \\
\hline$\rho$ & $\begin{array}{l}-0.0080 \\
(-0.075)\end{array}$ & $\begin{array}{l}-0.0200 \\
(-0.1865)\end{array}$ & $\begin{array}{l}-0.0180 \\
(-0.1672)\end{array}$ & & & \\
\hline$\lambda$ & & & & $\begin{array}{l}0.0380 \\
(0.3463)\end{array}$ & $\begin{array}{l}0.0004 \\
(0.0035)\end{array}$ & $\begin{array}{l}-0.0140 \\
(-0.1250)\end{array}$ \\
\hline $\mathrm{R}^{2}$ & 0.2996 & 0.1785 & 0.3105 & 0.2996 & 0.1784 & 0.3103 \\
\hline
\end{tabular}

In the South Asia region, we analyze the 5 countries. We find no evidence of energy productivity convergence process for both SAR and SEM panel data models as shown in Columns (1)-(6) in Table 3b. This indicates that there is an evidence of divergence process of energy productivity in the South Asia region. Concerning the coefficients of the control variables, we find only trade openness variable has the anticipated sign (Table 3b). The estimated coefficient on the trade openness variable is positively related with energy productivity growth and statistically significant (only Column (4)). We find mixed results on the investment variable (either positive or negative) and the estimated coefficient on the investment variable is positively related with the energy productivity growth (Columns (2), (5) and (6)), but statistically insignificant. Most of the estimated coefficient on the energy price variable is negative, but statistically significant as given in Columns (1)-(6). The results of spatial autoregressive coefficient $(\rho)$ and spatial error coefficient $(\lambda)$ demonstrate negative signs, but have a significant effect on the neighboring economies as reported in Columns (1)-(6) in Table $3 \mathrm{~b}$.

From the North East Asia region, our analysis considers 5 countries. The estimated $\beta$-coefficient is still negative and statistically significant in both SAR and SEM panel data models as shown in Columns (1)-(6) in Table 3b. It is observed that there exists a convergence process in energy productivity in the North East Asia region over the study period. Concerning the control variables, we find only trade openness variable has the expected sign (Table 3b). We find mixed results on the energy price variable (either positive or negative) and the estimated coefficient on the energy price variable is positive and statistically significant as reported in Columns (2), (3), (5) and (6) in Table 3b. This indicates that the energy price variable has a positive effect on energy productivity growth. Whereas in Columns (1) and (4), the estimated coefficient on the energy price variable is negative and statistically insignificant. The estimated coefficient on the trade openness variable is positively related with energy productivity growth and statistically significant as given in Columns (2), (3), (5) and (6) in Table 3b. On the other hand, most of the estimated coefficient on the investment variable is negative, but statistically significant as shown in Columns (2), (3), (5) and (6) in Table 3b. The spatial autoregressive coefficient $(\rho)$ and spatial error coefficient $(\lambda)$ exhibit negative signs, whereas significant effect on the adjoining economies (Table $3 b)$.

In the North Asia region, we examine the 5 countries. We find the estimated $\beta$-coefficient is negative and statistically significant in both SAR and SEM panel data models (Columns (1) and (4) in Table 3b). This indicates that there is an evidence of energy productivity convergence process in the North Asia region. While in Columns (2), (3), (5) and (6) in Table $3 \mathrm{~b}$ represent the divergence of energy productivity in the North Asia region over the study period. We find anticipated signs when considering the control variables except investment variable (Table $3 b$ ). The estimated coefficients on the trade openness and energy price variables are positive and highly statistically significant (Columns (1) to (6)). It can be noticed that the trade openness and energy price have a positive impact on energy productivity growth over the study period. Conversely, the estimated coefficient on the investment variable is negatively connected with energy productivity growth and statistically significant in Columns (1)-(6). The results of spatial autoregressive coefficient $(\rho)$ and spatial error coefficient $(\lambda)$ 
reveal negative signs, but significant effect on the adjoining economies as shown in columns (2), (3), (5) and (6) in Table 3b.

Finally, we investigate the 13 countries from the West Asia region. The estimated $\beta$-coefficient is negative and statistically significant for the SAR and the SEM panel data models (Columns (3) and (6) in Table 3b). It seems that there exists a conditional beta-convergence process in the West Asia region. Whereas in Columns (1), (2), (4) and (5) show the divergence process of energy productivity in the West Asia region over the study period. We find only trade openness variable is of expected sign (Table $3 b$ ). The estimated coefficient on the trade openness variable is positively related with energy productivity growth and statistically significant (Columns (1) and (4). In contrast, the coefficient on the energy price variable is negative and statistically insignificant (Columns (1)(6)). Likewise, the estimated coefficient on the investment variable is negatively related with energy productivity growth and highly statistically significant (Columns (1)-(6)). The estimated results of spatial autoregressive coefficient $(\rho)$ and spatial error coefficient $(\lambda)$ show negative signs (Columns (1)-(6) in Table 3b).

Table 3b. Estimation results of the conditional beta-convergence for five geographical regions

\begin{tabular}{|c|c|c|c|c|c|c|}
\hline & \multicolumn{3}{|c|}{ Spatial lag (SAR) panel data model } & \multicolumn{3}{|c|}{ Spatial error (SEM) panel data model } \\
\hline & $\begin{array}{l}\text { Spatial fixed } \\
\text { effects (1) }\end{array}$ & $\begin{array}{l}\text { Time-period } \\
\text { fixed effects (2) }\end{array}$ & $\begin{array}{l}\text { Spatial and time-period } \\
\text { fixed effects ( } 3 \text { ) }\end{array}$ & $\begin{array}{l}\text { Spatial fixed } \\
\text { effects (4) }\end{array}$ & $\begin{array}{l}\text { Time-period } \\
\text { fixed effects (5) }\end{array}$ & $\begin{array}{l}\text { Spatial and time-period } \\
\text { fixed effects }(6)\end{array}$ \\
\hline \multicolumn{7}{|c|}{ South East Asia } \\
\hline $\ln (\mathrm{EP})$ & $\begin{array}{l}-0.2277 * * \\
(-2.0725)\end{array}$ & $\begin{array}{l}-0.2638 * * * \\
(-2.7536)\end{array}$ & $\begin{array}{l}-0.2999 * * * \\
(-3.0710)\end{array}$ & $\begin{array}{l}-0.2212 * * \\
(-2.0513)\end{array}$ & $\begin{array}{l}-0.14920 * \\
(-1.4271)\end{array}$ & $\begin{array}{l}-0.2114 * \\
(-1.9166)\end{array}$ \\
\hline $\ln (\mathrm{P})$ & $\begin{array}{l}0.0995^{*} \\
(1.5296)\end{array}$ & $\begin{array}{l}0.0431 \\
(0.8283)\end{array}$ & $\begin{array}{l}0.0556 \\
(1.0603)\end{array}$ & $\begin{array}{l}0.0945^{*} \\
(1.4558)\end{array}$ & $\begin{array}{l}0.0413 \\
(0.7028)\end{array}$ & $\begin{array}{l}0.0640 \\
(1.0556)\end{array}$ \\
\hline $\ln (\mathrm{I})$ & $\begin{array}{l}-0.7504 * \\
(-1.4838)\end{array}$ & $\begin{array}{l}-0.4814 \\
(-1.2302)\end{array}$ & $\begin{array}{l}-0.5939 * \\
(-1.5790)\end{array}$ & $\begin{array}{l}-0.7403 * \\
(-1.4375)\end{array}$ & $\begin{array}{l}0.0909 \\
(0.1780)\end{array}$ & $\begin{array}{l}-0.0590 \\
(-0.1223)\end{array}$ \\
\hline $\ln (\mathrm{TO})$ & $\begin{array}{l}0.6713 * \\
(1.5757)\end{array}$ & $\begin{array}{l}0.9088^{*} \\
(1.4580)\end{array}$ & $\begin{array}{l}1.2906^{*} \\
(1.8344)\end{array}$ & $\begin{array}{l}0.6135 * \\
(1.4854)\end{array}$ & $\begin{array}{l}0.4048 * \\
(1.3225)\end{array}$ & $\begin{array}{l}0.9003 * \\
(1.6293)\end{array}$ \\
\hline$\rho$ & $\begin{array}{l}-0.2120 \\
(-1.0527)\end{array}$ & $\begin{array}{l}-0.8300^{* * *} \\
(-4.8769)\end{array}$ & $\begin{array}{l}-0.7960 * * * \\
(-4.6280)\end{array}$ & & & \\
\hline$\lambda$ & & & & $\begin{array}{l}-0.0920 \\
(-0.4489)\end{array}$ & $\begin{array}{l}-0.8120 * * * \\
(-4.4993)\end{array}$ & $\begin{array}{l}-0.7620^{* * *} \\
(-4.0934)\end{array}$ \\
\hline $\mathrm{R}^{2}$ & 0.2419 & 0.6243 & 0.6606 & 0.2068 & 0.2521 & 0.3481 \\
\hline \multicolumn{7}{|c|}{ South Asia } \\
\hline $\ln (\mathrm{EP})$ & $\begin{array}{l}0.0352 \\
(0.9325)\end{array}$ & $\begin{array}{l}0.0262 \\
(0.6415)\end{array}$ & $\begin{array}{l}0.0401 \\
(0.9519)\end{array}$ & $\begin{array}{l}0.0678 * * * \\
(2.3675)\end{array}$ & $\begin{array}{l}0.0736^{*} \\
(1.5144)\end{array}$ & $\begin{array}{l}0.0915 * \\
(1.7987)\end{array}$ \\
\hline $\ln (\mathrm{P})$ & $\begin{array}{l}-0.2185^{* *} \\
(-2.1648)\end{array}$ & $\begin{array}{l}-0.1255^{*} \\
(-1.4226)\end{array}$ & $\begin{array}{l}-0.1397^{*} \\
(-1.6053)\end{array}$ & $\begin{array}{l}-0.3167^{* * *} \\
(-3.5988)\end{array}$ & $\begin{array}{l}-0.1940^{* *} \\
(-2.0669)\end{array}$ & $\begin{array}{l}-0.2048^{* *} \\
(-2.2151)\end{array}$ \\
\hline $\ln (\mathrm{I})$ & $\begin{array}{l}-0.1339 \\
(-0.3874)\end{array}$ & $\begin{array}{l}0.1323 \\
(0.2644)\end{array}$ & $\begin{array}{l}-0.0017 \\
(-0.0034)\end{array}$ & $\begin{array}{l}-0.0264 \\
(-0.1267)\end{array}$ & $\begin{array}{l}0.4154 \\
(0.7640)\end{array}$ & $\begin{array}{l}0.2299 \\
(0.4191)\end{array}$ \\
\hline $\ln (\mathrm{TO})$ & $\begin{array}{l}0.1813 \\
(0.7424)\end{array}$ & $\begin{array}{l}0.0716 \\
(0.2540)\end{array}$ & $\begin{array}{l}0.1540 \\
(0.5330)\end{array}$ & $\begin{array}{l}0.2730^{*} \\
(1.5021)\end{array}$ & $\begin{array}{l}0.0342 \\
(0.1054)\end{array}$ & $\begin{array}{l}0.1115 \\
(0.3294)\end{array}$ \\
\hline$\rho$ & $\begin{array}{l}-0.3150 * \\
(-1.3422)\end{array}$ & $\begin{array}{l}-0.7730^{* * *} \\
(-3.9235)\end{array}$ & $\begin{array}{l}-0.7610^{* * *} \\
(-3.8372)\end{array}$ & & & \\
\hline$\lambda$ & & & & $\begin{array}{l}-0.7300^{* * *} \\
(-3.5340)\end{array}$ & $\begin{array}{l}-0.9290 * * * \\
(-5.5624)\end{array}$ & $\begin{array}{l}-0.8810^{* * *} \\
(-4.9576)\end{array}$ \\
\hline $\mathrm{R}^{2}$ & 0.2359 & 0.4868 & 0.5137 & 0.1281 & 0.1151 & 0.1879 \\
\hline North $E$ & t Asia & & & & & \\
\hline $\ln (\mathrm{EP})$ & $\begin{array}{l}-0.1441 * \\
(-1.4313)\end{array}$ & $\begin{array}{l}-0.4505 * * * \\
(-4.5333)\end{array}$ & $\begin{array}{l}-0.5794 * * * \\
(-5.5175)\end{array}$ & $\begin{array}{l}-0.1048 * \\
(-1.3070)\end{array}$ & $\begin{array}{l}-0.5195^{* * *} \\
(-4.4830)\end{array}$ & $\begin{array}{l}-0.7137 * * * \\
(-6.4069)\end{array}$ \\
\hline $\ln (\mathrm{P})$ & $\begin{array}{l}-0.0015 \\
(-0.0099)\end{array}$ & $\begin{array}{l}0.2022 * * \\
(1.9921)\end{array}$ & $\begin{array}{l}0.3611 * * * \\
(3.2056)\end{array}$ & $\begin{array}{l}-0.0411 \\
(-0.3087)\end{array}$ & $\begin{array}{l}0.2059 * \\
(1.7883)\end{array}$ & $\begin{array}{l}0.4473 * * * \\
(3.7604)\end{array}$ \\
\hline $\ln (\mathrm{I})$ & $\begin{array}{l}-0.9843 \\
(-1.1281)\end{array}$ & $\begin{array}{l}-3.0035^{* * *} \\
(-3.5046)\end{array}$ & $\begin{array}{l}-3.8442 * * * \\
(-4.6595)\end{array}$ & $\begin{array}{l}-0.2254 \\
(-0.2994)\end{array}$ & $\begin{array}{l}-3.3871 * * * \\
(-3.1721)\end{array}$ & $\begin{array}{l}-4.5217 * * * \\
(-4.8396)\end{array}$ \\
\hline $\ln (\mathrm{TO})$ & $\begin{array}{l}0.4070 \\
(0.9880)\end{array}$ & $\begin{array}{l}1.6996 * * * \\
(3.9405)\end{array}$ & $\begin{array}{l}2.2378 * * * \\
(4.8407)\end{array}$ & $\begin{array}{l}0.0726 \\
(0.2306)\end{array}$ & $\begin{array}{l}1.8760 * * * \\
(3.7712)\end{array}$ & $\begin{array}{l}2.7183 * * * \\
(5.6020)\end{array}$ \\
\hline
\end{tabular}




\begin{tabular}{|c|c|c|c|c|c|c|}
\hline$\rho$ & $\begin{array}{l}-0.6310 * * * \\
(-3.0335)\end{array}$ & $\begin{array}{l}-0.9199 * * * \\
(-6.7967)\end{array}$ & $\begin{array}{l}-0.8360 * * * \\
(-5.7251)\end{array}$ & & & \\
\hline$\lambda$ & & & & $\begin{array}{l}-0.6120^{* * *} \\
(-2.7362)\end{array}$ & $\begin{array}{l}-0.9139 * * * \\
(-5.3631)\end{array}$ & $\begin{array}{l}-0.9800 * * * \\
(-6.3272)\end{array}$ \\
\hline $\mathrm{R}^{2}$ & 0.4996 & 0.7878 & 0.8340 & 0.2564 & 0.5066 & 0.6395 \\
\hline \multicolumn{7}{|c|}{ North Asia } \\
\hline $\ln (\mathrm{EP})$ & $\begin{array}{l}-0.1262 * * * \\
(-2.5760)\end{array}$ & $\begin{array}{l}0.0359 \\
(0.6599)\end{array}$ & $\begin{array}{l}0.0275 \\
(0.5199)\end{array}$ & $\begin{array}{l}-0.1251 * * * \\
(-2.7398)\end{array}$ & $\begin{array}{l}0.0403 \\
(0.7732)\end{array}$ & $\begin{array}{l}0.0340 \\
(0.6930)\end{array}$ \\
\hline $\ln (\mathrm{P})$ & $\begin{array}{l}0.1495^{* * *} \\
(3.4416)\end{array}$ & $\begin{array}{l}0.0771 * * \\
(2.1716)\end{array}$ & $\begin{array}{l}0.0840 * * * \\
(2.4974)\end{array}$ & $\begin{array}{l}0.1516^{* * *} \\
(3.3120)\end{array}$ & $\begin{array}{l}0.0874 * \\
(1.8574)\end{array}$ & $\begin{array}{l}0.0896 * * \\
(2.0328)\end{array}$ \\
\hline $\ln (\mathrm{I})$ & $\begin{array}{l}-1.2757 * * * \\
(-2.7313)\end{array}$ & $\begin{array}{l}-0.8955^{* * *} \\
(-2.4901)\end{array}$ & $\begin{array}{l}-1.1139 * * * \\
(-3.1021)\end{array}$ & $\begin{array}{l}-1.3345^{* * *} \\
(-2.9106)\end{array}$ & $\begin{array}{l}-0.6869^{*} \\
(-1.8184)\end{array}$ & $\begin{array}{l}-0.9649 * * * \\
(-2.5452)\end{array}$ \\
\hline $\ln (\mathrm{TO})$ & $\begin{array}{l}0.6684 * * \\
(1.9938)\end{array}$ & $\begin{array}{l}1.4937 * * * \\
(4.4238)\end{array}$ & $\begin{array}{l}1.4089 * * * \\
(4.2742)\end{array}$ & $\begin{array}{l}0.5503 * \\
(1.7512)\end{array}$ & $\begin{array}{l}1.8036^{* * *} \\
(5.0230)\end{array}$ & $\begin{array}{l}1.6600 * * * \\
(4.7544)\end{array}$ \\
\hline$\rho$ & $\begin{array}{l}-0.1220 \\
(-0.5904)\end{array}$ & $\begin{array}{l}-0.6340 * * * \\
(-3.4712)\end{array}$ & $\begin{array}{l}-0.5600^{* * *} \\
(-3.3898)\end{array}$ & & & \\
\hline$\lambda$ & & & & $\begin{array}{l}-0.2359 \\
(-0.9498)\end{array}$ & $\begin{array}{l}-0.8930^{* * *} \\
(-4.0382)\end{array}$ & $\begin{array}{l}-0.9467 * * * \\
(-4.4396)\end{array}$ \\
\hline $\mathrm{R}^{2}$ & 0.5380 & 0.7458 & 0.7740 & 0.5254 & 0.6362 & 0.6777 \\
\hline \multicolumn{7}{|c|}{ West Asia } \\
\hline $\ln (\mathrm{EP})$ & $\begin{array}{l}-0.0398 \\
(-0.9887)\end{array}$ & $\begin{array}{l}-0.0787 \\
(-1.1514)\end{array}$ & $\begin{array}{l}-0.2035 * * * \\
(-3.0504)\end{array}$ & $\begin{array}{l}-0.0466 \\
(-1.1638)\end{array}$ & $\begin{array}{l}-0.0850 \\
(-1.2034)\end{array}$ & $\begin{array}{l}-0.2194 * * * \\
(-3.1972)\end{array}$ \\
\hline $\ln (\mathrm{P})$ & $\begin{array}{l}-0.0130 \\
(-0.3698)\end{array}$ & $\begin{array}{l}-0.0156 \\
(-0.3738)\end{array}$ & $\begin{array}{l}-0.0042 \\
(-0.1200)\end{array}$ & $\begin{array}{l}-0.0079 \\
(-0.2178)\end{array}$ & $\begin{array}{l}-0.0108 \\
(-0.2547)\end{array}$ & $\begin{array}{l}-0.0037 \\
(0.1054)\end{array}$ \\
\hline $\ln (\mathrm{I})$ & $\begin{array}{l}-1.5240 * * * \\
(-6.4838)\end{array}$ & $\begin{array}{l}-1.4218^{* * *} \\
(-4.8142)\end{array}$ & $\begin{array}{l}-1.3854 * * * \\
(-5.5917)\end{array}$ & $\begin{array}{l}-1.4970 * * * \\
(-6.2768)\end{array}$ & $\begin{array}{l}-1.3911 * * * \\
(-4.6527)\end{array}$ & $\begin{array}{l}-1.3629 * * * \\
(-5.3751)\end{array}$ \\
\hline $\ln (\mathrm{TO})$ & $\begin{array}{l}0.9435^{* * *} \\
(3.5013)\end{array}$ & $\begin{array}{l}0.3882 \\
(0.9733)\end{array}$ & $\begin{array}{l}0.3707 \\
(1.1642)\end{array}$ & $\begin{array}{l}0.9371^{* * *} \\
(3.4144)\end{array}$ & $\begin{array}{l}0.3893 \\
(0.9489)\end{array}$ & $\begin{array}{l}0.3603 \\
(1.0949)\end{array}$ \\
\hline$\rho$ & $\begin{array}{l}-0.3099^{*} \\
(-1.9144)\end{array}$ & $\begin{array}{l}-0.2840^{*} \\
(-1.6554)\end{array}$ & $\begin{array}{l}-0.2980^{*} \\
(-1.8663)\end{array}$ & & & \\
\hline$\lambda$ & & & & $\begin{array}{l}-0.0530 \\
(-0.3003)\end{array}$ & $\begin{array}{l}-0.1780 \\
(-0.9765)\end{array}$ & $\begin{array}{l}-0.0990 \\
(-0.5533)\end{array}$ \\
\hline $\mathrm{R}^{2}$ & 0.5663 & 0.3945 & 0.6400 & 0.5407 & 0.3635 & 0.6194 \\
\hline
\end{tabular}

Note. The t-values are in parentheses. *, ** and $* * *$ indicate statistical significance at the $10 \%, 5 \%$ and $1 \%$ levels of significance.

In general, we find strong evidence of the conditional beta-convergence process in energy productivity growth for all sample countries as well as two sub-sample countries: South East Asia and North East Asia. Furthermore, we find mixed evidence of a conditional beta-convergence process in energy productivity growth for two sub-sample countries: North Asia and West Asia. On the other hand, we find no evidence of a conditional beta-convergence process in energy productivity growth in the South Asia region. Our results shows trade openness has a positive impact on energy productivity growth for all sample countries and five sub-sample countries over the study period. It is noted that trade openness has become a major determinant factor in the process of convergence of energy productivity in 35 Asian countries. Therefore, trade openness has become an important contributor to exchange the technology in these countries. Our analysis finds that energy price variable has a very limited support for the energy productivity growth for 35 Asian countries and sub-sample countries. Likewise, our analysis shows investment variable plays an insignificant role in explaining energy productivity growth for all sample countries and five sub-sample countries over the study period. Our results overall shows spatial autoregressive coefficient $(\rho)$ and spatial error coefficient $(\lambda)$ are negative signs, but statistically significant on the adjoining economies.

Based on these results, the SAR and SEM panel data models show somehow similar results in terms of sign, and statistically significant. However, magnitudes of the coefficients are quite different from each other. We observe that both spatial and time period effects results are reliable than spatial fixed effects and time period effects for the SAR and the SEM panel data models (Columns (1)-(6) in Tables 2a-b and 3a-b). Overall, we find evidence of a beta-convergence process in energy productivity growth for the full sample countries. This result is consistent with the results of Markandya et al. (2006) and Wan et al. (2013), who found the convergence in 
energy intensity or productivity from EU countries. In addition, similar results were obtained by $\mathrm{Yu}$ (2012) for a panel of 30 provinces of China.

\section{Conclusions and Policy Implications}

This study has analyzed the convergence of energy productivity for 35 Asian countries spanning the period from 1993 to 2010. The present study not only investigates the entire set of Asian countries but also investigates five different geographical regions, namely, South East Asia, South Asia, North East Asia, North Asia and West Asia. We first used the sigma-convergence approach to investigate the disparity of energy productivity over time. We then used the beta-convergence model to estimate whether there exists an evidence of convergence in energy productivity applying the spatial panel data models. The sigma-convergence demonstrates a weak evidence of convergence process in energy productivity for all sample countries and mixed evidence for sub-sample countries. We find an absolute beta-convergence process in favor of energy productivity for all sample countries as well as North East Asia and West Asia during the study period. This implies a gap of energy productivity is decreasing in these Asian countries. Moreover, our estimated results reveal that there exists a conditional beta-convergence process in energy productivity for 35 Asian countries as well as South East Asia and North East Asia. We find mixed evidence (either convergence or divergence) of conditional beta-convergence in energy productivity for the North Asia and West Asia regions. In the South Asia region, we find no evidence of convergence process in energy productivity over the study period. Our analysis finds trade openness variable plays a significant role in energy productivity growth in Asia. It is pointed out that energy price variable has a limited support for energy productivity growth and investment variable does not support energy productivity growth in our study. It is also found that cross-countries spatial spillover effect is an insignificant in energy productivity growth.

From a policy perspective, it is not possible all Asian countries to follow the same energy policy because there is a vast difference in terms of economic activity and energy productivity. Therefore, these countries should focus on promoting international trade, exchanging information and technology transfer in order to reduce the differences in energy productivity. Furthermore, our results suggest that convergence process might imply a diffusion of energy related technological progress and divergence might imply promote energy saving policy in Asia.

Future research can be expanded the analysis at the sectoral level of energy productivity convergence within a specific country and across countries. Moreover, it is needed to investigate other control variables such as human capital, R\&D and foreign direct investment that have a significant inflation on the improvement of energy productivity growth in the future.

\section{Acknowledgements}

The first author thanks the Ministry of Education, China Scholarship Council (CSC), for providing financial support to conduct this research.

\section{References}

Aldy, J. E. (2006). Per capita carbon dioxide emissions: convergence or divergence? Environmental and Resource Economics, 33, 533-555. http://dx.doi.org/10.1007/s10640-005-6160-x

Anselin, L., Gallo, J. L., \& Jayet, H. (2008). Spatial panel econometrics. In L. Mátyás \& P. Sevestre (Eds.), The econometrics of panel data (pp. 625-660). Berlin, German: Springer-Verlag Berlin Heidelberg. http://dx.doi.org/10.1007/978-3-540-75892-1_19

Barro, R. J. (1991). Economic growth in a cross-section of countries. Quarterly Journal of Economics, 106(2), 407-443. http://dx.doi.org/10.2307/2937943

Barro, R. J., \& Sala-i-Martin, X. (1992). Convergence. Journal of Political Economy, 100, 223-251. http://www.jstor.org/stable/2138606

Barro, R. J., \& Sala-i-Martin, X. (1995). Economic growth. New York: McGraw Hill.

Baumol, W. J. (1986). Productivity growth, convergence and welfare: what the long-run data show. American Economic Review, 76, 1072-1085. http://www.jstor.org/stable/1816469

Baumol, W. J., Nelson, R. R., \& Wolff, E. N. (1994). Convergence and productivity; cross-national studies and historical evidence. Oxford: Oxford University Press. 
Bernard, A. B., \& Jones, C. I. (1996a). Comparing apples to oranges: productivity convergence and measurement across industries and countries. American Economic Review, 86, 1216-1238. http://www.jstor.org/stable/2118287

Bernard, A. B., \& Jones, C. I. (1996b). Productivity and convergence across US states and industries. Empirical Economics, 21, 113-135. http://dx.doi.org/10.1007/BF01205496

Carlino, G. A., \& Mills, L. (1996). Testing neoclassical convergence in regional incomes and earnings. Regional Science and Urban Economics, 26, 565-590. http://dx.doi.org/10.1016/S0166-0462(96)02137-0

Coulombe, S. (2000). New evidence of convergence across Canadian provinces: The role of urbanization. Regional Studies, 34(8), 713-725. http://dx.doi.org/10.1080/00343400050192810

Cuadrado-Roura, J., Garcia-Greciano, B., \& Raymond, J. L. (1999). Regional convergence in productivity and productive structure: the Spanish case. International Regional Science Review, 22, 35-53. http://dx.doi.org/10.1177/016001799761012190

DeLong, J. B. (1988). Productivity growth, convergence, and welfare: A comment. American Economic Review, 78, 1138-1154. http://www.jstor.org/stable/1807174

Duro, J. A., \& Padilla, E. (2011). Inequality across countries in energy intensities: an analysis of the role of energy transformation and final energy consumption. Energy Economics, 33, 474-479. http://dx.doi.org/10.1016/j.eneco.2010.12.008

Elhorst, J. P. (2003). Specification and estimation of spatial panel data models. International Regional Science Review, 26(3), 244-268. http://dx.doi.org/10.1177/0160017603253791

Elhorst, J. P. (2010). Spatial panel data models. In M. M. Fischer \& A. Getis (Eds.), Handbook of applied spatial analysis: Software tools, methods and applications (pp. 377-407). Berlin: Springer Berlin Heidelberg. http://dx.doi.org/10.1007/978-3-642-03647-7_19

Ezcurra, R. (2007a). Is there a cross-country convergence in carbon dioxide emissions? Energy Policy, 35, 1363-1372. http://dx.doi.org/10.1016/j.enpol.2006.04.006

Ezcurra, R. (2007b). Distribution dynamics of energy intensities: a cross-country analysis. Energy Policy, 35, 5254-5259. http://dx.doi.org/10.1016/j.enpol.2007.05.006

Fan, C. C., \& Casetti, E. (1994). The spatial and temporal dynamics of US regional income inequality, 19501989. The Annals of Regional Science, 28, 177-196. http://dx.doi.org/10.1007/BF01581768

Heston, A., Summers, R., \& Atten, B. (2012). Penn World Tables version 7.1. center for international comparisons of production, incomes and prices (CICUP). University of Pennsylvania. Retrieved from https://pwt.sas.upenn.edu/php_site/pwt71/pwt71_form.php

Hsiao, C. (1986). Analysis of panel data. Cambridge: Cambridge University Press.

International Energy Agency. (2010). World energy outlook. IEA, France. Retrieved from http://www.iea.org

International Monetary Fund. (2011). World economic outlook: Slowing Growth, Rising Risks. http://www.imf.org/external/index.htm

Islam, N. (1995). Growth empirics: a panel data approach. Quarterly Journal of Economics, 4, 1127-1170. http://dx.doi.org/doi:10.2307/2946651

Islam, N. (2003). Productivity dynamics in a large sample of countries: a panel study. Review of Income and Wealth, 49, 247-272. http://dx.doi.org/10.1111/1475-4991.00085

Izraeli, O., \& Murphy, K. (1997). Convergence in state nominal and real per capita income: empirical evidence. Public Finance Review, 25(6), 555-576. http://dx.doi.org/10.1177/109114219702500601

Jakob, M., Haller, M., \& Marschinski, R. (2012). Will history repeat itself? Economic convergence and convergence in energy use patterns. Energy Economics, 34, 95-104. http://dx.doi.org/10.1016/j.eneco.2011.07.008

Le Pen, Y., \& Sevi, B. (2010). On the non-convergence of energy intensities: evidence from a pair-wise $\begin{array}{lllll}\text { econometric } & \text { Epproach. } & \text { Ecological 641-650. }\end{array}$ http://dx.doi.org/10.1016/j.ecolecon.2009.10.001

Liddle, B. (2009). Electricity intensity convergence in IEA/OECD countries: aggregate and sectoral analysis. Energy Policy, 37, 1470-1478. http://dx.doi.org/10.1016/j.enpol.2008.12.006 
Liddle, B. (2010). Revisiting world energy intensity convergence for regional differences. Applied Energy, 87, 3218-3225. http://dx.doi.org/doi:10.1016/j.apenergy.2010.03.030

Markandya, A., Pedroso-Galinato, S., \& Streimikiene, D. (2006). Energy intensity in transition economies: is there convergence towards the EU average? Energy Economics, 28, 121-145. http://dx.doi.org/10.1016/j.eneco.2005.10.005

Matheson, T. D., \& Oxley, L. (2007). Convergence in productivity across industries: some results for New Zealand and Australia. International Review of Applied Economics, 21(1), 55-73. http://dx.doi.org/10.1080/02692170600874143

Meng, M., Payne, J. E., \& Lee, J. (2013). Convergence in per capita energy use among OECD countries. Energy Economics, 36, 536-545. http://dx.doi.org/10.1016/j.eneco.2012.11.002

Miketa, A., \& Mulder, P. (2005). Energy productivity across developed and developing countries in 10 manufacturing sectors: patterns of growth and convergence. Energy Economics, 27, 429-453. http://dx.doi.org/10.1016/j.eneco.2005.01.004

Miller, S. M., \& Upadhyay, M. P. (2002). Total factor productivity and the convergence hypothesis. Journal of Macroeconomics, 24, 267-286. http://dx.doi.org/10.1016/S0164-0704(02)00022-8

Mulder, P., \& De Groot, H. L. F. (2007). Sectoral energy- and labour-productivity convergence. Environmental and Resource Economics, 36, 85-112. http://dx.doi.org/ 10.1007/s10640-006-9042-y

Mulder, P., Florax, R. J. G. M., \& De Groot, H. L. F. (2011). A spatial perspective on global energy productivity trends. In R. J. G. M. Florax, H. L. F. de Groot, \& P. Mulder (Eds.), Improving energy efficiency through technology: trends, investment behaviour and policy design (pp. 23-66). Edward Elgar, Cheltenham. http://dx.doi.org/ 10.4337/9780857930606.00009

Rey, S., \& Montouri, B. (1999). US regional income convergence: a spatial econometric perspective. Regional Studies, 33(2), 143-156. http://dx.doi.org/10.1080/00343409950122945

Romero-Ávila, D. (2008). Convergence in carbon dioxide emissions among industrialised countries revisited. Energy Economics, 30, 2265-2282. http://dx.doi.org/10.1016/j.eneco.2007.06.003

Salinas-Jime'nez, M. M. (2003). Technological change, efficiency gains and capital accumulation in labor productivity growth and convergence: An application to the Spanish regions. Applied Economics, 35, 18391851. http://dx.doi.org/10.1080/000368403100016289800

Solow, R. M. (1956). A contribution to the theory of economic growth. Quarterly Journal of Economics, 70(1), 65-94. http://dx.doi.org/10.2307/1884513

Strazicich, M. C., \& List, J. A. (2003). Are $\mathrm{CO}_{2}$ emission levels converging among industrial countries? Environmental and Resource Economics, 24, 263-271. http://dx.doi.org/10.1023/A:1022910701857

Sun, J. W. (2002). The decrease in the difference of energy intensities between OECD countries from 1971 to 1998. Energy Policy, 30, 631-635. http://dx.doi.org/10.1016/S0301-4215(02)00026-5

Swan, T. W. (1956). Economic growth and capital accumulation. Economic Record, 32, 334-361. http://dx.doi.org/10.1111/j.1475-4932.1956.tb00434.x

Wan, J., Baylis, K., \& Mulder, P. (2013). Trade-facilitated spillovers in energy productivity convergence across EU countries. The selected works of Kathy Baylis. http://works.bepress.com/kathy_baylis/52

Westerlund, J., \& Basher, S. A. (2008). Testing for convergence in carbon dioxide emissions using a century of panel data. Environmental and Resource Economics, 40, 109-120. http://dx.doi.org/10.1007/s10640-007-9143-2

Wolff, E. N. (1991). Capital formation and productivity convergence over the long term. The American Economic Review, 81(3), 565-579. http://www.jstor.org/stable/2006519

World Bank. (2013). World Development Indicators. World Bank, Washington DC. http://data.worldbank.org

Yu, H. (2012). The influential factors of China's regional energy intensity and its spatial linkages: 1988-2007. Energy Policy, 45, 583-593. http://dx.doi.org/10.1016/j.enpol.2012.03.009 


\section{Notes}

Note 1. See, for example, per capita income (Barro, 1991; Barro \& Sala-i-Martin, 1992, 1995; Islam, 1995; Izraeli \& Murphy, 1997; Rey \& Montouri, 1999; Coulombe, 2000).

Note 2. See, for example, labor productivity and total factor productivity (DeLong, 1988; Wolff, 1991; Baumol et al., 1994; Bernard \& Jones, 1996a; Miller \& Upadhyay, 2002; Islam, 2003; Salinas-Jime'nez, 2003; Matheson \& Oxley, 2007).

Note 3. www.mapsofworld.com

Note 4 . Convergence analysis is primarily based on the traditional neoclassical growth path toward a steady state (Solow, 1956; Swan, 1956).

Note 5. The selection of such variables is discussed thoroughly in papers (Miketa \& Mulder, 2005; Mulder \& De Groot, 2007).

Note 6 . The use of panel data sets offer a greater availability of degrees of freedom and reduce the collinearity among the explanatory variables as it improve the efficiency of estimations (Hsiao, 1986, p.2).

Note 7. In the present study, the weights $w_{i j}$ of the spatial matrix $W_{N}$ is the geographical location between countries $i$ and $j$. By convention, the diagonal elements are set to be zero and sum of the elements in each row is one.

Note 8. We performed fixed effects SAR panel and SEM panel data models by using MATLAB routines (adapted from Elhorst, 2010, www.regroningen.nl/elhorst).

\section{Copyrights}

Copyright for this article is retained by the author(s), with first publication rights granted to the journal.

This is an open-access article distributed under the terms and conditions of the Creative Commons Attribution license (http://creativecommons.org/licenses/by/3.0/). 